\title{
Review of the source characteristics of the Great Sumatra-Andaman Islands earthquake of 2004
}

\author{
William Menke · Hannah Abend · Dalia Bach • \\ Kori Newman • Vadim Levin
}

Accepted: 30 August 2006/Published online: 1 November 2006

(C) Springer Science+Business Media B.V. 2006

\begin{abstract}
The December 26, 2004 Sumatra-Andaman Island earthquake, which ruptured the Sunda Trench subduction zone, is one of the three largest earthquakes to occur since global monitoring began in the 1890 s. Its seismic moment was $M_{0}=1.00 \times 10^{23}-1.15 \times 10^{23} \mathrm{Nm}$, corresponding to a moment-magnitude of $M_{w}=9.3$. The rupture propagated from south to north, with the southerly part of fault rupturing at a speed of $2.8 \mathrm{~km} / \mathrm{s}$. Rupture propagation appears to have slowed in the northern section, possibly to $\sim 2.1 \mathrm{~km} / \mathrm{s}$, although published estimates have considerable scatter. The average slip is $\sim 5 \mathrm{~m}$ along a shallowly dipping $\left(8^{\circ}\right), \mathrm{N} 31^{\circ} \mathrm{W}$ striking thrust fault. The majority of slip and moment release appears to have been concentrated in the southern part of the rupture zone, where slip locally exceeded $30 \mathrm{~m}$. Stress loading from this earthquake caused the section of the plate boundary immediately to the south to rupture in a second, somewhat smaller earthquake. This second earthquake occurred on March 28, 2005 and had a moment-magnitude of $M_{w}=8.5$.
\end{abstract}

Keywords Great earthquake $\cdot$ Source mechanism $\cdot$ Seismic moment · Seismic magnitude $\cdot$ Rapid hazard assessment $\cdot$ Indonesia $\cdot$ Sumatra $\cdot$ Tsunami $\cdot$ Andaman Islands

\section{Introduction}

The $M_{w}=9.3$ December 26, 2004 Sumatra-Andaman Island earthquake is the largest earthquake since the moment-magnitude $M_{w}=9.61960$ Chile and the

W. Menke $(\bowtie) \cdot$ H. Abend $\cdot$ D. Bach $\cdot$ K. Newman

Lamont-Doherty Earth Observatory of Columbia University, 1000, Palisades, NY 10964-8000, USA

e-mail: menke@ldeo.columbia.edu

V. Levin

Department of Geology, Wright Geological Laboratory, Rutgers University, 610 Taylor Road, Busch Campus, Piscataway, NJ 08854, USA 
$M_{w}=9.41964$ Alaska earthquakes occurred more than 30 years ago (Stein and Okal 2005; Tsai et al. 2005; E. Okal, personal communication, 2005). The earthquake occurred in a complex tectonic region, along the boundaries of the Indo-Australian and Eurasian plates, the Sunda and Burma microplates and the Andaman subplate (Fig. 1). It ruptured the subduction zone megathrust plate boundary on the Sunda Trench (Bird 2003).

The December earthquake and its tsunami caused tremendous devastation to the Indian Ocean region. An accounting by the United Nations estimates that 229,866 persons were lost, including 186,983 dead and 42,883 missing, with an additional 1,127,000 people displaced (United Nations Office of the Special Envoy for Tsunami Recovery 2006). The shaking registered clearly on seismometers worldwide (Park et al. 2005a, b). The earthquake strongly excited low degree free oscillations of the earth, so that the globe rang like a bell for several days afterward (Park et al. 2005a, b; Rosat et al. 2005). Static deformation, as determined by the Global Position System (GPS), exceeded $0.1 \mathrm{~m}$ for hundreds of kilometers around the epicenter (Catherine et al. 2005; Khan and Gudmundsson 2005). The amplitude of its Rayleigh wave exceeded $0.1 \mathrm{~m}$ at Diego Garcia (2,900 km distant), and $0.006 \mathrm{~m}$ in New York $(15,000 \mathrm{~km}$ distant $)$. Its effects were felt around the world, triggering seismicity at Mount Wrangell, a volcano in Alaska (West et al. 2005). Acoustic vibrations traversed the world oceans, and were recorded on several hydroacoustic arrays (Garcés et al. 2005). Seismic intensities near the rupture zone were, however, surprisingly small for such a large event, with northern Sumatra experiencing only intensity VIII on the EMS-98 scale (Martin 2005).

The first and larger mainshock was due to low angle thrust faulting with a nucleation point (hypocenter) at latitude $3.3^{\circ} \mathrm{N}$, longitude $96.0^{\circ} \mathrm{E}$ with an origin (start time) of 00:58:53.5 UTC (Figs. 1, 2, 3a) (Nettles and Ekström 2004). Its hypocentral depth, $28 \mathrm{~km}$, was shallow (Harvard CMT). The faulting propagated 1,200-1,300 km northeastward along the Sunda Trench (Ammon et al. 2005; Ni et al. 2005; Vigny et al. 2005 ) with a downdip width of $\sim 200 \mathrm{~km}$ (Ammon et al. 2005). The mainshock was followed by over 2,500 aftershocks with magnitudes greater than 3.8. In the several months following the mainshock, these aftershocks mostly occurred in a region northward of the nucleation point. However, a second large earthquake of momentmagnitude $M_{w}=8.5$ occurred on March 28, 2005. This second mainshock nucleated $\sim 170 \mathrm{~km}$ south of the first, at latitude $2.1^{\circ} \mathrm{N}$, longitude $97.0^{\circ} \mathrm{E}$ at 16:09:36 UTC, with the faulting propagating southeastward along the plate boundary for $\sim 300 \mathrm{~km}$ (Bilham 2005). This event was followed by aftershocks as well. The two regions of aftershocks delineate the respective rupture zones of the two mainshocks (Fig. 1).

Although the immediate area of the December 26, 2004 mainshock had been previously active, only a few aftershocks occurred there. One of the most notable aftershock features is the swarm of strike-slip and normal faulting events that occurred between $7.5-8.5^{\circ} \mathrm{N}$ and $94-95^{\circ} \mathrm{E}$ involving more than $150 M \geq 5$ earthquakes that occurred from January 27-30 (Lay et al. 2005).

\section{Tectonic setting}

The tectonics of the Sumatra-Andaman Island region is controlled by the boundaries between the Indo-Australian plate and by two segments of the southeastern section of the Eurasian plate, the Burma and Sunda subplates (Fig. 1) (Bird 2003). 

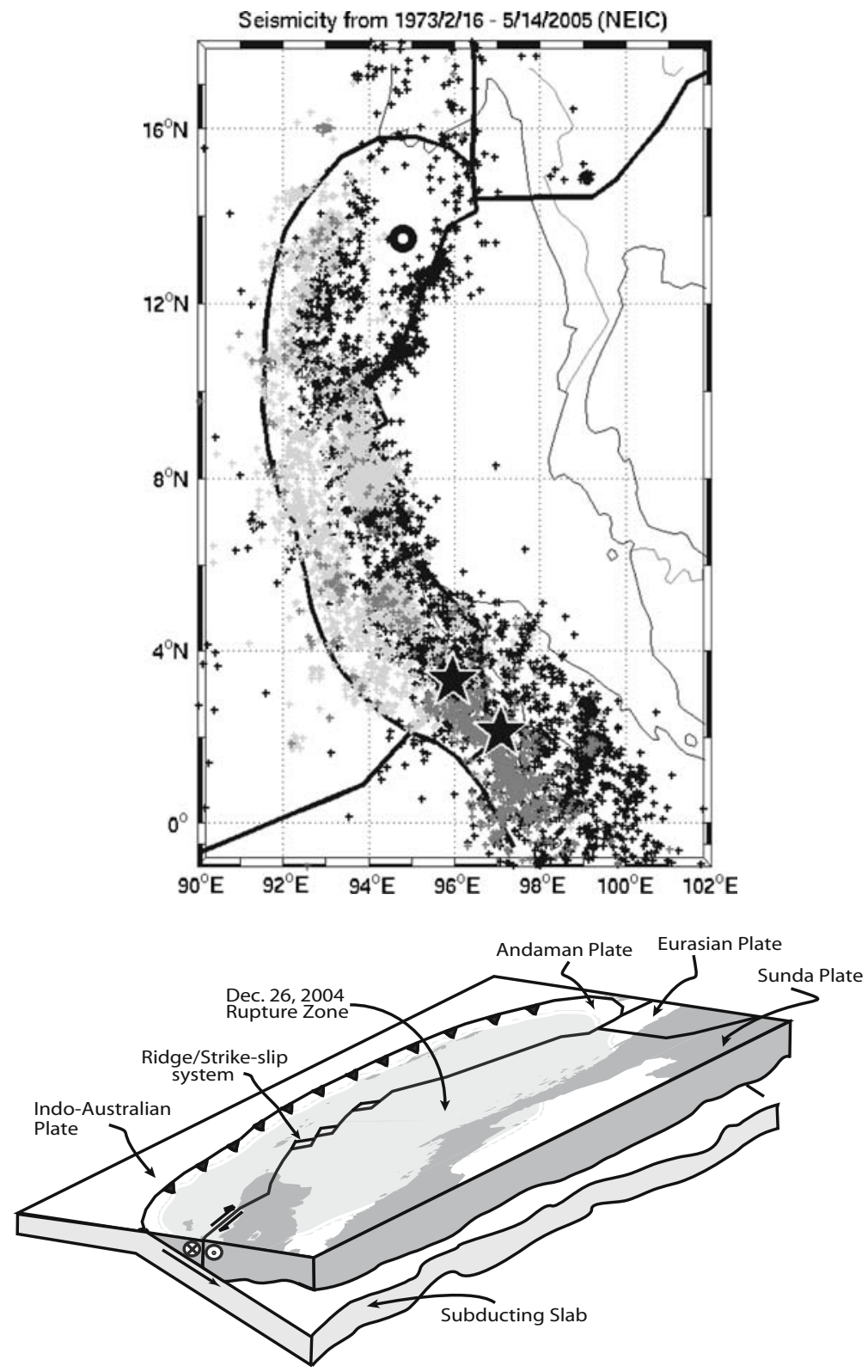

Fig. 1 Top Seismicity of the Sumatra-Andaman Island region. Stars the hypocenters of the December and March mainshocks (northerly and southerly, respectively). Black crosses background seismicity from February 16, 1973 through May 14, 2005 for events of magnitude >3.8. White crosses aftershocks of the December mainshock. Gray crosses aftershocks of the March mainshock. Solid lines coastlines. Bold lines plate boundaries (adapted from Bird 2003). Circle Indian-Burma Euler pole. Seismicity data from the National Earthquake Information Center in Boulder, CO. Bottom Three-dimensional sketch of the Sumatra-Andaman Island region 


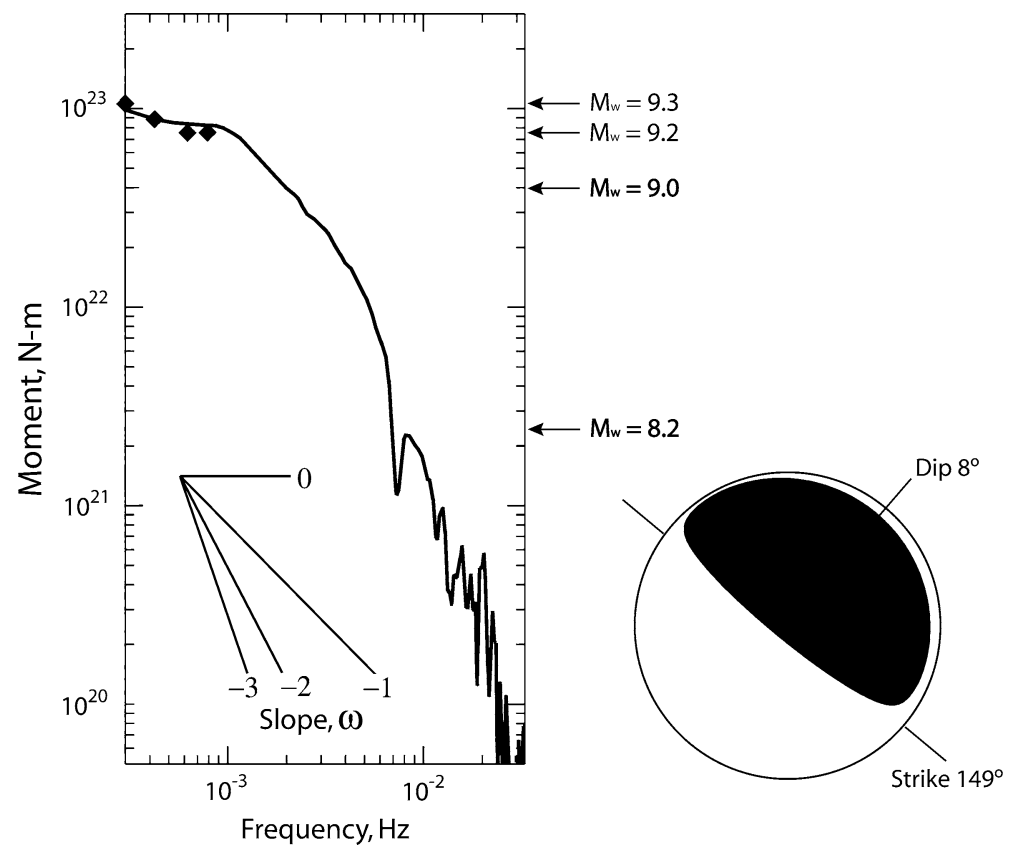

Fig. 2 Left Moment and moment-magnitude, $M_{w}$, estimates of the 2004 Sumatra-Andaman Island earthquake, as a function of frequency. Bold curve estimates from seismic waves. Diamonds estimates from low-degree free oscillations. Note that estimates drop off rapidly with frequency from their low frequency asymptote of $M_{w}=9.3$, to $M_{w}=8.2$ at a frequency of $7 \times 10^{-3} \mathrm{~Hz}(150 \mathrm{~s}$ period $)$, at a rate consistent with an $\omega^{-2}$ falloff rate (where $\omega$ is angular frequency). This behavior emphasizes the difficulty in making accurate moment estimates with high frequency data. Right The focal mechanism of the earthquake indicates that it occurred on a low-angle thrust fault with a strike similar to the regional trend of the plate boundary. Data from Lay et al. (2005) and Nettles and Ekström (2005)

The Indo-Australian plate is moving north-northwestward at about $45-60 \mathrm{~mm} / \mathrm{year}$ with respect to the Sunda subplate (Bird 2003). The Indian-Burma Euler pole is at latitude $13.5^{\circ} \mathrm{N}$, longitude $94.8^{\circ} \mathrm{E}$, implying subduction of the Indian plate under the Burma plate along the part of the plate boundary that is to the south of the pole, and strike-slip motion on the more northerly part of the plate boundary that is to the east of the pole (Fig. 1) (Bird 2003).

The plate boundary east of the Himalayas trends southward toward the Andaman and Nicobar Islands, and then turns eastward south of Sumatra along the Java trench (Lay et al. 2005). The region accommodates the obliquely convergent plate motion by a trench-parallel strike-slip fault system that interacts with the subduction zone, defining the $1,900 \mathrm{~km}$ long Sumatran fault. It cuts through the hanging wall of the Sumatran subduction zone from the Sunda strait to the ridges of the Andaman Sea (Sieh and Natawidjaja 2000). The Andaman trench is undergoing oblique thrust motion at a convergence rate of about $14 \mathrm{~mm} /$ year (Bock et al. 2003). The interface between the India plate and the Burma plate is a thrust fault that dips $\sim 8^{\circ}$ to the northeast (Nettles and Ekström 2004). Back-arc ridges accommodate the remaining plate motion by seafloor spreading along a plate boundary that connects to the Sumatra fault to the south (Fig. 1). The oblique motion between the Indo-Australian plate and the Burma and Sunda subplates has caused a plate sliver (or "microplate") 

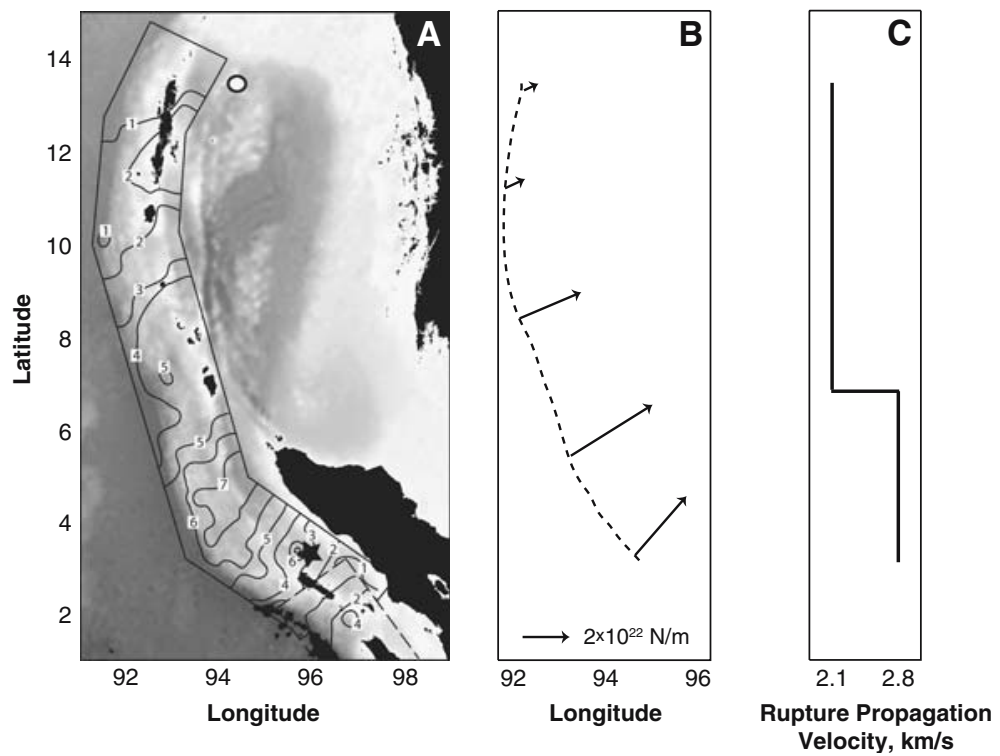

Fig. 3 Diagrams of slip characteristics along the rupture zone of the December mainshock. (a) Slip, contoured in meters (adapted from Ammon et al. 2005). (b) Variations in slip direction (azimuth of arrows) and seismic moment (length of arrows) along the strike of the rupture zone (data from Tsai et al. 2005). c Along-strike variation of rupture velocity (data from Tolstoy and Bohnenstiehl 2005)

to be sheared off parallel to the subduction zone from Myanmar to Sumatra, termed the Andaman microplate (Bilham et al. 2005).

\section{Geodetic and seismic estimates of slip}

Banerjee et al. (2005), Catherine et al. (2005), Vigny et al. (2005) and Hashimoto et al. (2006) use far-field GPS data to constrain fault slip during the December mainshock. Using far-field GPS sites about 400-3,000 km from the rupture, they derived a slip model for this earthquake with a maximum slip of $30 \mathrm{~m}$. Banerjee et al. (2005) estimates the average slip along the rupture to be $\sim 5 \mathrm{~m}$. Hashimoto et al. (2006) suggests that coseismic slip as large as $14 \mathrm{~m}$ occurred beneath the Nicobar Islands. Gahalaut et al. (2006) improved slip resolution and rupture characteristics using coseismic displacements derived from near-field GPS. They estimate coseismic slip of 3.8-7.9 m under the Andaman Islands and 11-15 m under the Nicobar Islands. They also estimate coseismic horizontal ground displacement and vertical subsidence along the Andaman-Nicobar Islands of 1.5-6.5 and 0.5-2.8 m, respectively. Both geodetical and seismological slip models agree that the largest slip occurred near the southern end of the rupture zone and diminished northward (Ammon et al. 2005). This conclusion is supported by the multiple moment-tensor analysis of Tsai et al. (2005). In this analysis, five "sub-events" are placed along the rupture zone, and the moment tensor of each is determined through long-period waveform fitting. These sub-events can be roughly understood to mean patches, or segments, of the fault plane. In Tsai et al.'s (2005) analysis, the southern half of the rupture accounts for $72 \%$ of the overall moment release (Fig. 3b). 
Models of slip calculated from broadband seismic waveforms (Ammon et al. 2005) and from GPS data (Vigny et al. 2005; Bilham 2005) highlight two areas of especially high slip. The $4^{\circ} \mathrm{N}$ latitude of the southernmost high-slip area is the same in both models. Ammon et al. (2005) give $6^{\circ} \mathrm{N}$ for the northernmost, while Vignay et al. give $10^{\circ} \mathrm{N}$. The highest amplitude high-frequency $(>1 \mathrm{~Hz})$ seismic waves originate from the vicinity of these high-slip portions of the rupture zone (Tolstoy and Bohnenstiehl 2005; Krüger and Ohrnberger 2005).

\section{The rupture process}

Three lines of evidence clearly indicate that the fault ruptured from south to north:

(1) The duration of high-frequency $(>1 \mathrm{~Hz}) \mathrm{P}$ waves, which are believed to originate from the rupture front, is shortest for a propagation path that leaves the hypocentral region parallel to the $\sim \mathrm{N} 30^{\circ} \mathrm{W}$ strike of the subduction zone, and longest for a path with azimuth $180^{\circ}$ from that direction (Ammon et al. 2005; Ni et al. 2005). This pattern is consistent with the principle that the shortest duration is observed when the rupture is toward the station (Aki and Richards, Sect. 14.1, 1980), that is, to the north.

(2) The apparent arrival direction of high-frequency $(>1 \mathrm{~Hz})$ energy, as tracked by distant, small-aperture arrays, changes systematically with time in a sense consistent with northward propagation of the rupture front. This pattern is observed both in the seismically observed $\mathrm{P}$ wave and the hydroacoustically observed T wave (Ishii et al. 2005; Tolstoy and Bohnenstiehl 2005; de GrootHedlin 2005; Guilbert et al. 2005).

(3) The long-period $(0.005-0.02 \mathrm{~Hz})$ seismograms are best fit by a sequence of five sub-events placed along the fault, with the origin time of each sub-event increasing from south to north (Tsai et al. 2005). The pattern indicates that the main slip on the southern parts of the fault occurred before that of the northern parts. Dynamic source theory (Aki and Richards, Sect. 15, 1980) indicates that the majority of fault slip occurs shortly after the passage of the rupture front. Hence this pattern is also consistent with a south-to-north rupture propagation.

Rupture velocity estimates vary, but most analyses agree that the rupture occurred in two broad phases, an initial fast rupture at $2.8 \mathrm{~km} / \mathrm{s}$ that lasted $200 \mathrm{~s}$ and which broke the southern $500-600 \mathrm{~km}$ of the fault, immediately followed by a slower second phase of rupture that broke the remaining, northern section (Fig. 3b). Estimates of the velocity of this second phase are more variable: Tolstoy and Bohnenstiehl (2005) give $2.1 \mathrm{~km} / \mathrm{s}$, Guilbert et al. (2005) give 2.1-2.5 km/s and de Groot-Hedlin (2005) gives $1.5 \mathrm{~km} / \mathrm{s}$. Ishii et al. (2005) detects no decrease in velocity, and gives the constant velocity of $2.8 \mathrm{~km} / \mathrm{s}$ over the whole $1,200 \mathrm{~km}$ of rupture.

The direction of the slip, as determined by Tsai et al.'s (2005) sub-event analysis, is northeasterly and rotates clockwise from south to north. This rotation is consistent with the overall arcuate shape of the subduction zone (Fig. 3c).

One still-controversial aspect of the faulting is the total time duration of the slip, and especially whether it continued long past the initial $480 \mathrm{~s}$ of rupture front propagation. Bilham (2005) argues that the slip may have continued for a further $1,320 \mathrm{~s}$. His argument is based on the lack of any clear corner frequency in the 
earthquake's spectrum (at least at frequencies $>4 \times 10^{-4} \mathrm{~Hz}$, see Fig. 2), a feature whose corresponding period $(2,500 \mathrm{~s}$, in this case) is normally associated with time scale of rupture. This association, however, is only valid for the highly idealized case of a point source in a whole space, and may break down for faults whose size is a substantial fraction of the earth's diameter. Vigny et al. argues against slow slip in the Andaman-Nicobar region and suggests that the entire displacement at GPS sites in the northern Thailand occurred in less than $600 \mathrm{~s}$ after the origin. The distributed source model of Tsai et al. (2005) achieves a good fit to the long-period seismic data and a large moment $\left(M_{w}=9.3\right)$, with the rather short duration of slip of $\sim 150 \mathrm{~s}$ at each point on the fault. Nevertheless, it is clear that seismic data are only weakly sensitive to fault processes that have time scales that approach (or exceed) the period of the lowest-degree mode of free oscillations of the earth $(\sim 3,230 \mathrm{~s})$. Further research is needed on this subject to completely resolve this issue.

\section{Estimates of moment and magnitude}

Kerr (2005) dramatically recounts the confusion that reigned within the seismological community during the initial hours following the Sumatra-Andaman Island earthquake, especially concerning its magnitude. Initial estimates (e.g., the U.S. Geological Survey's Fast Moment Tensor Solution) were as low as $M_{w}=8.2$, but rose over the next several hours to $M_{w}=9.0$ (Nettles and Ekström 2004). While both these estimates indicate that the earthquake was extremely large, they have very different implications. Magnitude $\sim 8$ earthquakes occur globally at a rate of about once per year, and do not usually generate damaging, ocean-crossing tsunamis (teletsunamis). Magnitude $\sim 9$ earthquakes are much rarer, occurring at a rate of just a few per century, and have the potential for generating devastating teletsunamis. The most recent magnitude estimate, based on a very complete analysis of data from hundreds of seismometers worldwide, is $M_{w}=9.3$ (Stein and Okal 2005; Tsai et al. 2005), which places among the three largest earthquake to occur since seismic monitoring began in the 1890s (the other two being the $M_{w}=9.6$ Chilean earthquake of 1960 and the $M_{w}=9.4$ Alaska earthquake of 1964).

The magnitude assignment process was at least to some extent hindered by the rarity of events of this size: neither automated processing algorithms nor human analysts had had much previous experience with data from extremely large earthquakes. Experience gained in interpreting data from the many thousands of smaller earthquakes that occur each year did not fully carry over to this extreme event. But the problem also reflects a fundamental difference in opinion among seismologists about the meaning and proper use of seismic magnitude, and its relationship to another seismological parameter, the seismic moment.

Seismic moment, $M_{0}$, is the fundamental measure of the severity of the faulting that causes an earthquake. The seismological community is in broad agreement both on how to define seismic moment (it is the algebraic product of the fault's rupture area, its average slip, and the shear modulus of the surrounding rock) and how to measure it. The moment of the Sumatra-Andaman Island earthquake can be roughly estimated as $M_{0} \sim 1 \times 10^{23} \mathrm{Nm}$, assuming $5 \mathrm{~m}$ of average slip (determined geodetically) on a $1,200 \times 250 \mathrm{~km}$ fault (determined by the distribution of aftershocks) in a typical upper-mantle rock with a shear modulus of $7 \times 10^{10} \mathrm{~N} / \mathrm{m}^{2}$. Seismic moment can also be estimated seismologically, by waveform fitting of long-period seismograms. The 
most recent of these seismological estimates give very similar values: $1.0 \times 10^{23} \mathrm{Nm}$ (Stein and Okal 2005) and $1.15 \times 10^{23} \mathrm{Nm}$ (Tsai et al. 2005).

Seismic magnitude, on the other hand, is an assignment of the earthquake's strength that is based on measurements of the amplitude of seismic waves. Since Charles Richter's initial 1935 formulation, many different magnitude scales have been developed, using different seismic waves (e.g., the $m_{\mathrm{b}}$ scale that uses $1 \mathrm{~Hz}$ frequency $\mathrm{P}$ waves and the $M_{\mathrm{s}}$ scale that uses $0.05 \mathrm{~Hz}$ Rayleigh waves) and different data-processing strategies. Magnitudes assigned using these scales are broadly correlated with each other and also with seismic moment, but the relationship is inexact. Nevertheless, seismic magnitudes are not measurements of moment but rather are rough and uncalibrated estimates of the acoustic luminosity of the faulting process. This distinction has created a thorny problem in the seismological literature: is moment the authoritative descriptor of the size of an earthquake, for which magnitude is just a proxy? Or are moment and magnitude complementary descriptors, each of which illuminates a different aspect of and earthquake's size? Or, in the extreme view, are seismic magnitudes quantities with "no absolute meaning," which should be used only for statistical comparisons between groups of earthquakes (P.G. Richards, personal communication, 2005). In the first interpretation, an $m_{\mathrm{b}}$ (or an $M_{\mathrm{s}}$ ) that does not agree with an $M_{w}$ ought to be construed as erroneous. In the second and third, even wildly different $M_{w}, m_{\mathrm{b}}$ and $M_{\mathrm{s}}$ 's for the same earthquake are perfectly acceptable. In our opinion, the later choices are public outreach nightmares, since seismologists, when speaking to the press, rarely identify the type of magnitude that they are citing, and most members of the public are ill-prepared to appreciate the distinction, anyway.

Kanamori (1977) tried to sidestep this controversy by introducing the momentmagnitude, a quantity computed directly from moment according to the formula $M_{w}=2 \times \log _{10}\left(M_{0}\right) / 3-6.06$. Since it is derived from moment, $M_{w}$ is a direct measure of the severity of faulting. The constants in the formula have been chosen so that $M_{w}$ evaluates - at least when applied to a moderate-sized earthquake-to a numerical value similar to the traditional body-wave $\left(m_{\mathrm{b}}\right)$ and surface-wave $\left(M_{\mathrm{s}}\right)$ magnitude for that earthquake. Both the Stein and Okal (2005) and Tsai et al. (2005) moment estimates of the Sumatra-Andaman Island earthquake correspond to $M_{w}=9.3$. A criticism of moment-magnitude, however, is that $M_{w}$ is not a magnitude (that is, acoustic luminosity) at all, but is rather just a scaled version of seismic moment.

Seismologists routinely assign magnitude because it can be done quickly and consistently, without recourse to elaborate computer-based data analysis. This is in contrast to seismic estimates of moment, which require time-consuming wiggle-for-wiggle matching of observed and predicted seismograms. However, when used for a proxy for moment (that is, for $M_{w}$ ), seismic magnitudes, $m_{\mathrm{b}}$ and $M_{\mathrm{s}}$, are systematic downward biased, especially for the largest earthquakes. This fact has been well-known by seismologists since the 1970s (Aki 1972; Geller 1976). The problem is that the slip that occurs on a long fault is not instantaneous. Slip on a $1,200-\mathrm{km}$ long fault, such as Sumatra-Andaman Island, occurs over about $480 \mathrm{~s}$, because the rupture front propagates at a speed of about 2.1-2.8 km/s (Tolstoy and Bohnenstiehl 2005) from one end of the fault to the other. Consequently, the seismic waves that radiate from the fault are systematically deficient in energy at periods shorter than this characteristic time scale (that is, frequencies above $\sim 0.002 \mathrm{~Hz}$ ). Estimates of moment and moment-magnitude fall off rapidly with frequency as the minimum frequency used in the estimate increases. This effect is especially pronounced for frequencies above $\sim 10^{-3} \mathrm{~Hz}$ (Fig. 2). 
Standard procedures for calculating $m_{\mathrm{b}}$ and $M_{\mathrm{s}}$ use seismic waves with periods of 1 and $20 \mathrm{~s}$, respectively-much less than $480 \mathrm{~s}$ - and are systematically downward biased with respect to $M_{w}$ when applied to this extremely large earthquake. Unfortunately, it is not possible to correct this problem simply by deciding to measure the seismic magnitude of all earthquakes at a very low frequency. Small earthquakes have extremely poor signal-to-noise ratio at low frequencies. A useful magnitude estimation procedure must be applicable to the run-of-the-mill magnitude 5 earthquake, as well as to the rare magnitude 9.

\section{Rapid assessment and human impacts}

As discussed above, the initial analysis of this great earthquake was fraught with miscalculations of its magnitude. Early magnitude estimates were as low as $M_{w}=8.2$, fully 1.1 magnitude units below the current estimate of $M_{w}=9.3$. Initial estimates of fault length were also low-as low as $400 \mathrm{~km}$-consistent with the initially low estimate of magnitude, and only one-third of the current estimate of 1,200-1,300 km (Sieh 2005). These early underestimates marred the initial effort to assess the severity of this great earthquake, although other factors, and especially completely inadequate emergency planning at the global scale, arguably had a greater impact on the humanitarian response (Weinstein et al. 2005).

Seismologists recognize the shortcomings in the current rapid size assessment technology and emphasize the need for real-time monitoring as well as new techniques to improve magnitude calculations. Subsequent to the earthquake, several promising strategies have been proposed. Menke and Levin (2005) discuss a technique that uses $0.005-0.020 \mathrm{~Hz}$ P-wave amplitude ratios, calibrated against nearby smaller earthquakes with known moment, to estimate $M_{w}$. Lomax and Michelini (2005) use the duration of the high-frequency $(>1 \mathrm{~Hz}) \mathrm{P}$ wave to infer rupture duration, which when combined with an assumed rupture velocity provides an estimate of rupture zone length. This length estimate can then be converted to a moment (and hence an $M_{w}$ ) by assuming a scaling between length, width and slip. Tolstoy and Bohnenstiehl (2005), de Groot-Hedlin (2005) and Ishii et al. (2005) all use high-frequency $(>1 \mathrm{~Hz})$ beam-forming techniques to track the rupture front, and thus make a direct measurement of its length, which can then be scaled to a moment.

Given that the tsunami obliterated the coasts of Indonesia, India and Sri Lanka within just a few hours of its initiation, it is clear that size estimation strategies must produce a very rapid preliminary $M_{w}$ estimate in order to have any impact on the decision to issue a tsunami warning. All the techniques discussed above have the potential to determine $M_{w}$ within 30 min of the initiation of rupture. Those methods that use land-based seismometers (Menke and Levin 2005; Ishii et al. 2005) would work globally, even with existing instrumentation. Those that use hydroacoustic arrays (Tolstoy and Bohnenstiehl 2005; de Groot-Hedlin 2005) would require denser global hydrophone coverage to be practical, since the speed of acoustic waves though water $(1.5 \mathrm{~km} / \mathrm{s})$ is much slower than the speed of $\mathrm{P}$ waves through the earth's upper mantle $(8-10 \mathrm{~km} / \mathrm{s})$.

Nettles and Ekström's (2004) $M_{w}=9.0$ estimate for the Sumatra-Andaman Island earthquake, which used a waveform fitting approach, was issued about $4 \mathrm{~h}$ after the initiation of rupture. This time lag allows time for the relatively slow $(4 \mathrm{~km} / \mathrm{s})$ Rayleigh waves to traverse the globe, and thus for the overall dataset to be 
essentially complete. However, a preliminary estimate-but one that still uses frequencies in the $0.001-0.002 \mathrm{~Hz}$ range, and thus is appropriate for magnitude 9 earthquakes - could probably be achieved with substantially less time lag, by relying only on closer stations and the faster-propagating seismic phases (e.g., P, S).

The recurrence interval for an earthquake like Sumatra-Andaman Island is at least 400 years (Stein and Okal 2005). However, stress transfers along the Sunda trench increase the probability of triggering subsequent earthquakes on the surrounding faults (McCloskey et al. 2005). An example of this triggering is the $M_{w}=8.5$ rupture that occurred roughly $300 \mathrm{~km}$ to the south of the December 26th event (Vigny et al. 2005). Given the active nature of the tectonic structure in this region as well as the awareness that large earthquakes generally come in clusters (Sieh 2005), there is a real need to develop raid size estimation technology and efficient hazard warning systems.

Acknowledgments Our understanding of this important earthquake was informed by a semesterlong seminar, held at Columbia University in early 2005, that focused upon it and its associated tsunami. We thank its organizer, Paul Richards, and its many participants for many hours of extremely engaging discussion. Lamont-Doherty Contribution Number 6981.

\section{References}

Aki K (1972) Scaling laws of earthquake source time function. Geophys J R Astron Soc 34:3-25

Aki K, Richards PG (1980) Quantitative seismology, theory and methods. W.H. Freeman and Company, San Francisco, 922 pp

Ammon CJ, Ji C, Thio H-K, Robinson D, Ni S, Hjorleifsdottir V, Kanamori H, Lay T, Das S, Helmberger D, Ichinose G, Polet J, Wald D (2005) Rupture process of the 2004 SumatraAndaman earthquake. Science 308:1133-1139. DOI 10.1126/science. 1112260

Banerjee P, Pollitz FF, Bürgmann R (2005) The size and duration of the Sumatra-Andaman earthquake from far-field static offsets. Science 308:1769-1772. DOI 10.1126/science.1113746

Bilham R (2005) A flying start, then a slow slip. Science 308:1126-1127. DOI 10.1126/science. 1113363

Bilham R, Engdhal R, Feldl N, Satyabala SP (2005) Partial and complete rupture of the IndoAndaman Plate boundary 1847-2004. Seismol Res Lett 76: 299-311

Bird P (2003) An updated digital model of plate boundaries. Geochem Geophys Geosyst 4:1027. DOI 10.1029/2001GC000252

Bock Y, Prawirodirdjo L, Genrich JF, Stevens CW, McCaffrey R, Subarya C, Puntodewo SSO, Calais E (2003) Crustal motion in Indonesia from Global Positioning System measurements. J Geophys Res 108:Article No. 2367

Catherine JK, Gahalaut VK, Sahu VK (2005) Constraints on rupture of the December 26, 2004, Sumatra earthquake from far-field GPS observations. Earth Planet Sci Lett 237:673-679. DOI 10.1016/j.epsl.2005.07.012

Gahalaut VK, Nagarajan B, Catherine JK, Kumar S (2006) Constraints on 2004 Sumatra-Andaman earthquake rupture from GPS measurements in Andaman-Nicobar Islands. Earth Planet Sci Lett 242:365-374

Garcés M, Caron P, Hetzer C, Le Pichon A, Bass H, Drob D, Bhattacharyya J (2005) Deep infrasound radiated by the Sumatra earthquake and tsunami. Eos Trans AGU 86:317. DOI 10.1029/2005EO350002

Geller RJ (1976) Scaling relationships for earthquake source parameters and magnitudes. Bull Seismol Soc Am 66:1501-1523

de Groot-Hedlin CD (2005) Estimation of the rupture length and velocity of the Great Sumatra earthquake of Dec 26, 2004 using hydroacoustic signals. Geophys Res Lett 32:L11303. DOI 10.1029/2005GL022695

Guilbert J, Vergoz J, Schisselé E, Roueff A, Cansi Y (2005) Use of hydroacoustic and seismic arrays to observe rupture propagation and source extent of the $M_{w}=9.0$ Sumatra earthquake. Geophys Res Lett 32:L15310. DOI 10.1029/2005GL022966 
Hashimoto M, Choosakul N, Hashizume M, Takemoto S, Takiguchi H, Fukuda Y, Frjimori K (2006) Crustal deformations associated with the great Sumatra-Andaman earthquake deduced from continuous GPS observation. Earth Planets Space 58:127-139

Ishii M, Shearer PM, Houston H, Vidale JE (2005) Extent, duration and speed of the 2004 Sumatra-Andaman earthquake imaged by the Hi-Net array. Nature 435:933-936. DOI 10.1038/ nature 03675

Kanamori H (1977) The energy release in great earthquakes. J Geophys Res 82:2981-2987

Kerr RA (2005) South Asia tsunami: failure to gauge the quake crippled the warning effort. Science 307:201. DOI 10.1126/science.307.5707.201

Khan SA, Gudmundsson O (2005) GPS analyses of the Sumatra-Andaman earthquake. Eos Trans AGU 86:89. DOI 10.1029/2005EO090001

Krüger F, Ohrnberger M (2005) Tracking the rupture of the $M_{w}=9.3$ Sumatra earthquake over $1,150 \mathrm{~km}$ at teleseismic distance. Nature 435:937-939. DOI 10.1038/nature03696

Lay T, Kanamori H, Ammon CJ, Nettles M, Ward SN, Aster RC, Beck SL, Bilek SL, Brudzinski MR, Butler R, DeShon HR, Ekström G, Satake K, Sipkin S (2005) The Great Sumatra-Andaman earthquake of 26 December 2004. Science 308:1127-1133. DOI 10.1126/science.1112250

Lomax A, Michelini A (2005) Rapid determination of earthquake size for hazard warning. Eos Trans AGU 86:202. DOI 10.1029/2005EO210003

Martin SS (2005) Intensity distribution from the 2004 M 9.0 Sumatra-Andaman earthquake. Seismol Res Lett 76:321-330

McCloskey J, Nalbant SS, Steacy S (2005) Indonesian earthquake: earthquake risk from co-seismic stress. Nature 434:291. DOI 10.1038/434291a

Menke W, Levin V (2005) A strategy to rapidly determine the magnitude of great earthquakes. Eos Trans AGU 85:185. DOI 10.1029/2005EO190002

Nettles M, Ekström G (2004) Quick CMT of the 2004 Sumatra-Andaman Island earthquake. Seismoware FID: BR345, emailed announcement, 26 December 2004

Ni S, Kanamori H, Helmberger D (2005) Seismology: energy radiation from the Sumatra earthquake. Nature 434:582. DOI 10.1038/434582a

Park J, Alex Song TR, Tromp J, Okal E, Stein S, Roult G, Clevede E, Laske G, Kanamori H, Davis P, Berger J, Braitenberg C, Van Camp M, Lei X, Sun H, Xu H, Rosat S (2005a) Earth's free oscillations excited by the 26 December 2004 Sumatra-Andaman earthquake. Science 308:11391144. DOI 10.1126/science.1112305

Park J, Anderson K, Aster R, Butler R, Lay T, Simpson D (2005b) Global seismographic network records the Great Sumatra-Andaman earthquake. Eos Trans AGU 86:57. DOI 10.1029/ 2005EO060001

Rosat S, Sato T, Imanishii Y, Hinderer J, Tamura Y, McQueen H, Ohashi M (2005) High-resolution analysis of the gravest seismic normal modes after the $2004 M_{w}=9$ Sumatra earthquake using superconducting gravimeter data. Geophys Res Lett 32:L13304. DOI 10.1029/2005GL023128

Sieh K (2005) Aceh-Andaman earthquake: what happened and what's next? Nature 434:573-574. DOI $10.1038 / 434573 a$

Sieh K, Natawidjaja D (2000) Neotectonics of the Sumatran fault, Indonesia. J Geophys Res 105:28,295-28,326

Stein S, Okal EA (2005) Speed and size of the Sumatra earthquake. Nature 434:581-582. DOI $10.1038 / 434581 \mathrm{a}$

Tolstoy M, Bohnenstiehl DR (2005) Hydroacoustic constraints on the rupture duration, length, and speed of the Great Sumatra-Andaman earthquake. Seismol Res Lett 76:419-425

Tsai VC, Nettles M, Ekström G, Dziewonski A (2005) Multiple CMT source analysis of the 2004 Sumatra earthquake. Geophys Res Lett 32:L17304. DOI 10.1029/2005GL023813

United Nations Office of the Special Envoy for Tsunami Recovery (2006) The Human Toll, www.tsunamispecialenvoy.org/country/humantoll.asp

Vigny C, Simons WJF, Abu S, Bamphenyu R, Satirapod C, Choosakul N, Subarya C, Socquet A, Omar $\mathrm{K}$, Abidin HZ, Ambrosius BAC (2005) Insight into the 2004 Sumatra-Andaman earthquake from GPS measurements in southeast Asia. Nature 436:201-206. DOI 10.1038/nature03937

Weinstein S, McCreery C, Hirshorn B, Whitmore P (2005) Comment on "A strategy to rapidly determine the magnitude of great earthquakes" by W. Menke and V. Levin. Eos Trans AGU 86:263. DOI 10.1029/2005EO280005

West M, Sánchez JJ, McNutt SR (2005) Periodically triggered seismicity at Mount Wrangell, Alaska, after the Sumatra earthquake. Science 308:1144-1146. DO 10.1126/science.1112462 